\title{
Design Radial-Flux Mini Permanent Magnet Generator
}

\author{
Alex Wenda \\ Electrical Engineering Department, \\ Faculty of Science and Technology, UIN SUSKA Riau, Indonesia
}

\begin{abstract}
Utilization of renewable energy, such as water and wind always has constraints in the form of varying and not constant water or airflow velocity so that a generator is capable of working in that condition. This study aims to design a permanent magnet generator with a size calculated based on a target output power of 500 watts. The dimensions of the generator produced are calculated by the equation and produce a rotor diameter and core length of $108 \mathrm{~mm}$ and $52 \mathrm{~mm}$. The generator is designed to have 18 slots, 16 poles and 3 phases. The generator is tested with different speed variations and no load. No-load test results with variations in the speed of $50 \mathrm{rpm}, 250 \mathrm{rpm}, 500 \mathrm{rpm}$, and $1000 \mathrm{rpm}$ produces a voltage of 11.30 volts, 56.52 volts, 113.04 volts, 169.53 volts, and 226.08 volts. After that, the generator is tested with load variations $5 \Omega, 10 \Omega, 15 \Omega$, and $20 \Omega$ in order to get the value of its power and efficiency. The highest power produced at a speed of $500 \mathrm{rpm}$ is 580,791 watts. The highest power produced by the generator is at a speed of $1000 \mathrm{rpm}$ which is 1170.53 watts. the highest efficiency produced by this permanent magnet generator is $79.76 \%$.
\end{abstract}

Keywords - Efisiensi, Generator Magnet Permanen, Slot, Pole, Daya.

\section{INTRODUCTION}

Growth in population is increasing, this is directly proportional to the increasing amount of energy consumption. Electrical energy is one of the most widely used energy. Electricity consumption in the period 20002014 experienced an average growth of $6.8 \%$ per year [1]. With this growth, various methods are carried out so that the electrical energy needs are met. One way to do this is to use renewable energy.

One of the electrical energy devises to utilize renewable energy that is developed is a generator. Generator is a device to convert mechanical energy into electrical energy [2]. In a renewable electric energy generator, mechanical energy is the conversion of primary energy such as water and wind. Utilization of renewable energy such as water and wind always has constraints, where the speed of water and airflow varies and is not constant so it takes a generator that is able to work in these circumstances [3]. Generators that are able to work in these circumstances are permanent magnet generators.
Permanent magnet generators are very efficient to use because they work well at low rotational speeds [4]. Then in the manufacture and also scale-up of permanent magnet generators it is very easy to design generators with certain power capacities, certain voltages and certain work speeds by simply changing parameters such as magnetic flux, number of coils and number of turns, the number of magnets and diameter of wire [5]. Permanent magnet generators are divided into two, based on the magnetic flux produced, namely axial flux permanent magnet generators and radial flux permanent magnet generators [6].

\section{METHODOLOGY}

\section{A. Data Collection}

The data used in this design are dimension generator data and reference sheet data from the material. Dimension data is taken from standards established in the International Electrotechnical Commission (IEC) standard.

\section{B. Variable}

The variables in this study were divided into two, namely the design variable and test variable.

a. Design Variable

1. Dimensions of Permanent Magnet Generators

$$
D^{2} L=\frac{Q}{1.11 \pi^{2} B_{a v} a c K_{w} n_{s} 10^{-3}}
$$

\section{Size of Stator and Rotor Slots}

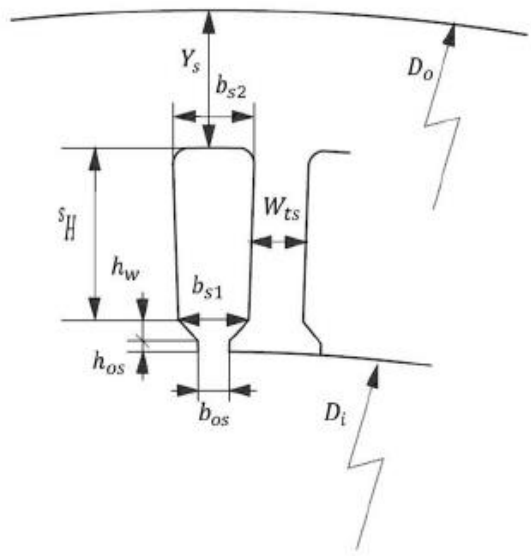

Fig 1:- Stator Topologi 


$$
S_{s}=p \cdot q \cdot m
$$

calculate Stator tooth $\left(W_{t s}\right)$ :

$$
W_{t s}=\frac{p \cdot B_{g} \cdot A_{p r}}{S_{s} L_{i} B_{t s}}
$$

Calculate area of rotor pole $\left(\mathrm{A}_{\mathrm{pr}}\right)$ :

$$
A_{p r}=\tau_{p} . L_{i}
$$

Stator pole pitch $\tau_{p}$ :

$$
\tau_{p}=\frac{\pi D}{p}
$$

Effective length core $L_{i}$ :

$$
L i=L . K_{\text {stack }}
$$

Diameter Rotor $D_{t}$ :

$$
D_{r}=D-2 . l_{g}
$$

Stator yoke $\mathrm{Y}_{\mathrm{s}}$ :

$$
Y_{s}=\frac{\phi}{2 L_{1} B_{t s}}
$$

Wide hole stator $A_{s s}$ :

$$
A_{s s}=\frac{A_{w} N_{s}}{F F}
$$

Calculate the area of a conductor's path:

$$
A_{w}=\frac{I_{p h}}{J}
$$

Calculate the diameter of a conductor $d_{w}$ :

$$
\begin{gathered}
d_{w}=\sqrt{\frac{4 \cdot A_{w}}{\pi}} \\
b_{s 1}=\frac{\pi\left(D_{i}+2 h_{o s}+2 h_{w}\right)}{S_{s}}-b_{t s} \\
b_{s 2}=\sqrt{4 \cdot A_{s s} \cdot \tan \frac{\pi}{s_{s}}}+b_{s 1}^{2} \\
h_{s}=\frac{2 \cdot A_{s s}}{b_{s 1}+b_{s 2}}
\end{gathered}
$$

Out side diameter $D$ :

$$
D_{o}=D+2 .\left(h_{s}+h_{o s}+h_{w}+Y_{s}\right)
$$

Magnetic Thickness:

$$
P C=\frac{t_{m}}{l_{g} C_{\phi}}
$$

Factor concentration flux:

$$
C_{\phi}=\frac{A_{m}}{A_{g}}=\frac{2 \alpha_{m}}{1+\alpha_{m}}
$$

Wide air gap:

b. Test Variable

$$
\alpha_{m}=\frac{\tau_{m}}{\tau_{p}}
$$

The test variable is a generator testing variable in the form of input from the generator and generator load..

1. Input Generator

The test variable for generator input is based on nonconstant air and water flow velocity, so that the generator is tested with different speeds, namely a range of $100 \mathrm{rpm}$ $1000 \mathrm{rpm}$.

\section{Load Generator}

The generator is connected to the load which aims to produce the current value as well as to find out the power produced by the generator. In addition, the provision of load also aims to determine the characteristics and efficiency of the generator. In this case the load given is $5 \mathrm{ohms}-20 \mathrm{ohms}$.

\section{Design and Simulation}

Mathematical calculations of permanent magnet generators are calculations to obtain values from the size or geometry of the generator. This mathematical calculation will produce a measure of the dimensions of the permanent magnet generator, namely $\mathrm{D}^{2} \mathrm{~L}$, where $\mathrm{L}$ is the core length and $\mathrm{D}$ is the diameter of the air gap. In addition to producing the main dimensions, the calculation will also produce stator, rotor and magnet size values. This calculation requires parameters as shown in table 1 below.

\begin{tabular}{|c|c|}
\hline Power, $\mathrm{P}$ & $500 \mathrm{Watt} / 588 \mathrm{VA}$ \\
\hline Specific magnetic loading, Bg & $0,9 \mathrm{~T}$ \\
\hline Specific electric loading, ac & $12.000 \mathrm{~A} / \mathrm{m}$ \\
\hline The angular velocity, Ns & $500 \mathrm{rpm} / 8,3 \mathrm{rps}$ \\
\hline Winding factor, $k_{w}$ & 0.945 \\
\hline Power factor, cos $\theta$ & 0.85 \\
\hline Number of Phasa, $\mathrm{N}_{\mathrm{ph}}$ & 3 \\
\hline Frekuency, $\mathrm{f}$ & $50 \mathrm{~Hz}$ \\
\hline Flux Density in Stator teeth, $\mathrm{B}_{\mathrm{ts}}$ & $1.5 \mathrm{~T}$ \\
\hline
\end{tabular}

Tabel 1:- Input parameter perhitungan Matematis Generator 
From the input parameters above, obtained the geometry specifications of the permanent magnet generator shown in table 2 .

\begin{tabular}{|l|l|}
\hline Stator outer diameter $(\mathrm{Db})$ & $190 \mathrm{~mm}$ \\
\hline Inside diameter of the slot hole $(\mathrm{De})$ & $170 \mathrm{~mm}$ \\
\hline Inside diameter of the stator $(\mathrm{Dc})$ & $110 \mathrm{~mm}$ \\
\hline Air gap stator and rotor $\left(l_{g}\right)$ & $1 \mathrm{~mm}$ \\
\hline Outer diameter of the rotor $(\mathrm{Dr})$ & $108 \mathrm{~mm}$ \\
\hline Magnetic outer diameter $(\mathrm{Di})$ & $105 \mathrm{~mm}$ \\
\hline Inner diameter of the magnet $(\mathrm{Da})$ & $98 \mathrm{~mm}$ \\
\hline Diameter shaft & $20 \mathrm{~mm}$ \\
\hline Magnet length & $16 \mathrm{~mm}$ \\
\hline Magnet Thicknes $\left(L_{m}\right)$ & $4 \mathrm{~mm}$ \\
\hline Teeth Length & $26.9 \mathrm{~mm}$ \\
\hline Teeth height $\left(L_{t}\right)$ & $3 \mathrm{~mm}$ \\
\hline Teet Widthh $\left(W_{t s}\right)$ & $11 \mathrm{~mm}$ \\
\hline Distance between slots $\left(L_{t g}\right)$ & $4.15 \mathrm{~mm}$ \\
\hline $\begin{array}{l}\text { Stator and rotor core length }\left(L_{a}\right), \\
\text { magnet }\left(L_{h}\right)\end{array}$ & $52 \mathrm{~mm}$ \\
\hline Thick Yoke $\left(Y_{S}\right)$ & $10 \mathrm{~mm}$ \\
\hline Number of pole $(p)$ & $16 \mathrm{pole}$ \\
\hline Number of slot $\left(Q_{S}\right)$ & 18 slot \\
\hline
\end{tabular}

Table 2:- Geometry specifications of permanent magnet generators

From the above specifications, the permanent magnet synchronous generator stator is designed as shown in Figure 2 . and the results of the rotor design are shown in Figure 3.

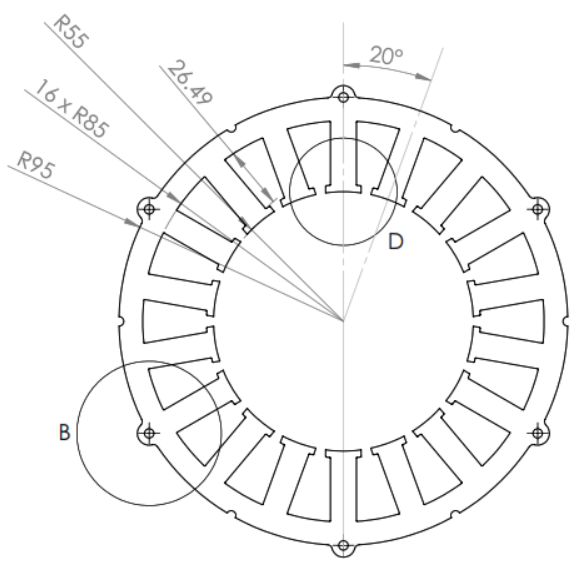

Fig 2:- Stator 18 slot 2D permanent synchronous generator design results

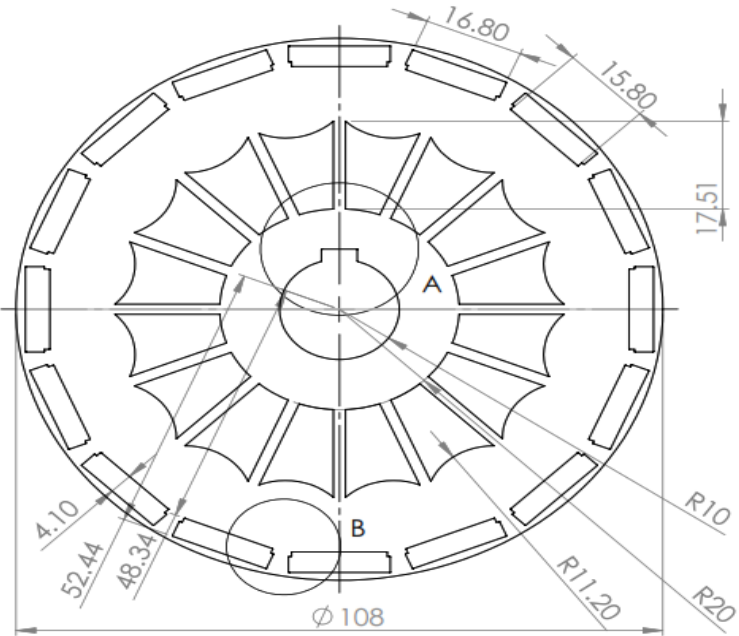

Fig 3:- The design of a 16 pole rotor 2D permanent magnet generator

The geometry design of permanent magnet generators will be given the composite material for each component. The components of a permanent magnet generator consist of the air box, stator, air gap, rotor, magnet, cooler, and shaft. The material making up the simulation of a permanent magnet generator is shown in table 3 .

\begin{tabular}{|c|c|}
\hline Komponen & Material \\
\hline Stator & $\begin{array}{c}\text { Non-Oriented M1000-100A } \\
\text { Silicon Steel }\end{array}$ \\
\hline Rotor & $\begin{array}{c}\text { Non-Oriented M1000-100A } \\
\text { Silicon Steel }\end{array}$ \\
\hline Air Box dan Air Gap & Air \\
\hline Permanent Magnet & Neodymium Iron Boron: 48/11 \\
\hline Coil & Copper: 5.77e7 Siemens/Meter \\
\hline Shaft & Air \\
\hline
\end{tabular}

Table 3:- Composite Material simulation of permanent magnet generator

Giving material to the stator and rotor is soft magnet material, this material shows its magnetic characteristics only when subjected to magnetic forces such as magnetic fields generated by permanent magnets or currents that cross the coil that surrounds these laminates. The most widely used soft magnet is silicon steel. The presence of silicon in steel can increase the resistivity volume to reduce eddy currents and reduce hysteresis. The silicon content in steel is approximately $0.5 \%-3.25 \%$. In addition, the use of soft magnetic materials also reduces the reluctance of the magnetic circuit, increases the saturation of the flux density, reduces losses and increases in temperature.

Figure 4 shows the results of designing a permanent magnet generator on the Magnet software. 


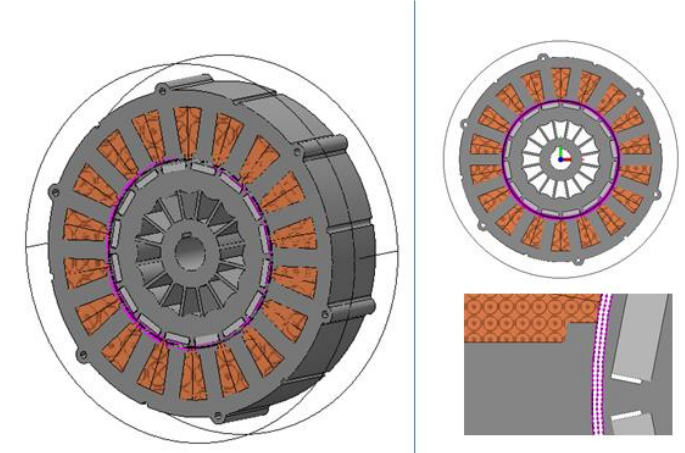

Fig 4:- Permanent magnet generator in the Magnet software

The generator works by changing the input in the form of rotational speed or angular speed (radians per second) and torque (Newton meters), producing an output in the form of a voltage (volts) and currents (amperes). The generator rotates with input through shafts from the turbine. Input from the turbine is turbine rotational speed, and torque is given.

In the simulation various variations of angular velocity will be tried. The parameters set in this simulation are the angular rotor speed $(\omega)$, and time. The speeds that were tried in this simulation were speeds at $50 \mathrm{rpm}, 250 \mathrm{rpm}, 500 \mathrm{rpm}$, $750 \mathrm{rpm}$ and $1000 \mathrm{rpm}$.

The rotor is part of a rotating generator. The rotor will rotate by 360 o for 1 spin. Rotational speed in units of rpm (rotation per minute) means that in one minute the rotor will rotate once, then it will be changed in units of degrees per second wherein one second the rotor will rotate by $360 \mathrm{o}$, so that,

$$
\begin{gathered}
50 \mathrm{rpm} \rightarrow \frac{50 \mathrm{rpm} \times 360^{\circ}}{60 \mathrm{~s}}=300^{\circ} / \mathrm{s} \\
250 \mathrm{rpm} \rightarrow \frac{250 \mathrm{rpm} \times 360^{\circ}}{60 \mathrm{~s}}=1500^{\circ} / \mathrm{s} \\
500 \mathrm{rpm} \rightarrow \frac{500 \mathrm{rpm} \times 360^{\circ}}{60 \mathrm{~s}}=3000^{\circ} / \mathrm{s} \\
750 \mathrm{rpm} \rightarrow \frac{750 \mathrm{rpm} \times 360^{\circ}}{60 \mathrm{~s} \times 360^{\circ}}=4500^{\circ} / \mathrm{s} \\
1000 \mathrm{rpm} \rightarrow \frac{1000 \mathrm{rpm} \times 000^{\circ} / \mathrm{s}}{60 \mathrm{~s}}=6
\end{gathered}
$$

The designed permanent magnet generator is an $18 \mathrm{~s} 16 \mathrm{p}$ permanent magnet generator, so to form one sinusoidal wave the rotor only needs to spin around $360 \mathrm{o} / 8$ $=45 \mathrm{o}$. In this simulation the rotor will be rotated per $3 \mathrm{o}$, so it needs to know-how much time it takes the rotor to rotate for 30 .

Time at a speed of $300 \mathrm{rps}$ when the rotor rotates $3^{0}$ :

Waktu pada kecepatan 300 rps saat rotor berputar $3^{\circ}$

$$
\rightarrow \frac{3^{\circ} \times 1 \mathrm{~s}}{300^{\circ}}=0.01 s
$$

Time at a speed of $1500 \mathrm{rps}$ when the rotor rotates $3^{0}$ :
Waktu pada kecepatan $1500 \mathrm{rps}$ saat rotor berputar $3^{\circ}$

$$
\rightarrow \frac{3^{\circ} \times 1 \mathrm{~s}}{1500^{\circ}}=0.002 \mathrm{~s}
$$

Time at a speed of $3000 \mathrm{rps}$ when the rotor rotates $3^{0}$ :

Waktu pada kecepatan 3000 rps saat rotor berputar $3^{\circ}$

$$
\rightarrow \frac{3^{\circ} \times 1 \mathrm{~s}}{3000^{\circ}}=0.001 s
$$

Time at a speed of $4500 \mathrm{rps}$ when the rotor rotates $3^{0}$ :

Waktu pada kecepatan $4500 \mathrm{rps}$ saat rotor berputar $3^{\circ}$

$$
\rightarrow \frac{3^{\circ} \times 1 \mathrm{~s}}{4500^{\circ}}=0.000667 \mathrm{~s}
$$

Time at a speed of $6000 \mathrm{rps}$ when the rotor rotates $3^{0}$ :

Waktu pada kecepatan $6000 \mathrm{rps}$ saat rotor berputar $3^{\circ}$

$$
\rightarrow \frac{3^{\circ} \times 1 \mathrm{~s}}{6000^{\circ}}=0.0005 \mathrm{~s}
$$

Magnet Software will simulate a start time from the above results. The rotor will rotate $45^{0}$ to form one sinusoidal wave, so because the simulation is calculated every 30 then $45^{0} / 3^{0}=15$, there will be 15 calculation data to form a sinusoidal wave, therefore it is necessary to determine the stop time of the simulation. To calculate stop time as follows :

Time stops at $300 \mathrm{rps}: 15 \times 0.01=0.15$

Time stops at 1500 rps: $15 \times 0.002=0.03$

Time stops at 3000 rps: $15 \times 0.001=0.015$

Time stops at $4500 \mathrm{rps}: 15 \times 0.000667=0.010005$

Time stops at $6000 \mathrm{rps}$ : $15 \times 0.0005=0.0075$

From the above calculation, we get the input parameters of permanent magnet generator on the Magnet software. The following calculation data is summarized in table 4.

\begin{tabular}{|c|c|c|c|}
\hline RPM & RPS & Stop Time & Interval/3 \\
\hline 50 & 300 & 0.15 & 0.01 \\
\hline 250 & 1500 & 0.03 & 0.002 \\
\hline 500 & 3000 & 0.015 & 0.001 \\
\hline 750 & 4500 & 0.010005 & 0.000667 \\
\hline 1000 & 6000 & 0.0075 & 0.0005 \\
\hline
\end{tabular}

Table 4:- Input Simulation parameters in Magnet software

\section{Generator Circuits in Magnet Software}

Making the circuit is the stage of making a circuit that is in a generator. The generator consists of 18 slots, this means there are 18 coils that will be connected to make 3 phases. In this design, the circuit configuration that will be made is a star configuration consisting of 6 series and 3 parallel so that it will get 3 phases.

In this study, a no-load circuit was created and a circuit with a load. For a no-load circuit will produce an inter-phase voltage value and the average DC the voltage used to 
determine the Back EMF constant, while a circuit with a load will produce voltage and current so that the power will be generated by the generator. The load used is the load on the obstacles $5 \Omega, 10 \Omega, 15 \Omega, 20 \Omega$. Figure 5 shows the circuit without load and Figure 6 shows the circuit with a load.

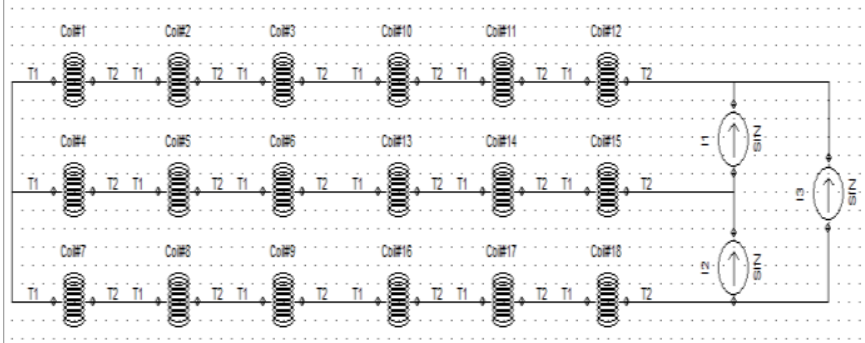

Fig 5:- Circuit Without load

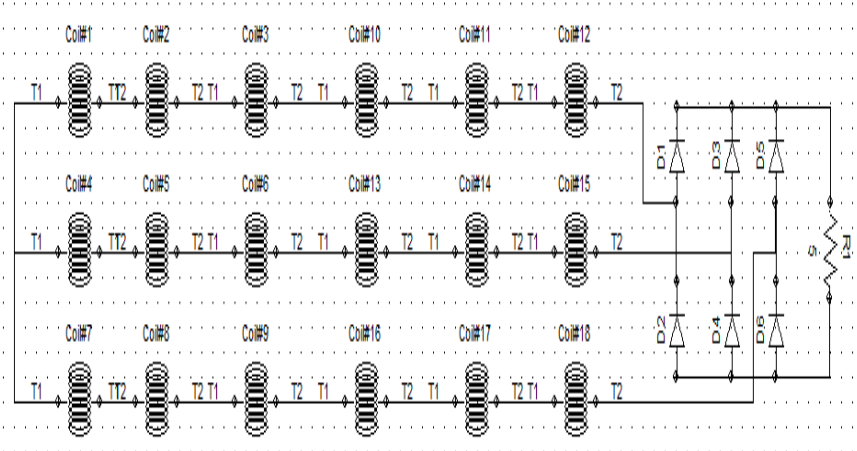

Fig 6:- Circuit With a load

\section{RESULT AND DISCUSSION}

A. Voltage and Back EMF Constant

Table 5 shows a summary of the voltage produced by the generator at each speed. This data shows that the faster the rotor in the generator rotates, the greater the voltage generated. This is in accordance with the rules of the right hand.

In this no-load simulation, the result is only a voltage and does not produce a current, because the generator is not connected to the load. There is a value of Ke or Back EMF constant which indicates that this generator is the same generator with different tests.

\begin{tabular}{|l|l|l|}
\hline Speed (rpm) & Average Voltage $(\mathbf{V})$ & $\boldsymbol{K}_{\mathbf{e}}$ \\
\hline $\mathbf{5 0}$ & 11.30458 & 2.16 \\
\hline $\mathbf{2 5 0}$ & 56.52263 & 2.16 \\
\hline $\mathbf{5 0 0}$ & 113.0445 & 2.16 \\
\hline $\mathbf{7 5 0}$ & 169.5258 & 2.16 \\
\hline $\mathbf{1 0 0 0}$ & 226.0858 & 2.16 \\
\hline
\end{tabular}

Table 5:- Voltage produced by the generator at each speed

\section{B. Input Power}

The test results as shown in table 6, if the load increases, the torque will be smaller, so the impact on input power.

\begin{tabular}{|l|l|l|l|l|}
\hline \multirow{2}{*}{$\begin{array}{l}\text { Speed } \\
(\mathbf{r p m})\end{array}$} & \multicolumn{4}{|l|}{ Input Power $($ P.In) watt } \\
\cline { 2 - 5 } & $\mathbf{5} \boldsymbol{\Omega}$ & $\mathbf{1 0} \boldsymbol{\Omega}$ & $\mathbf{1 5} \boldsymbol{\Omega}$ & $\mathbf{2 0} \boldsymbol{\Omega}$ \\
\hline $\mathbf{5 0}$ & 24.186 & 15.18726 & 11.5012 & 9.505 \\
\hline $\mathbf{2 5 0}$ & 356.1318 & 263.4993 & 203.8163 & 171.0234 \\
\hline $\mathbf{5 0 0}$ & 744.1821 & 738.532 & 645.0334 & 547.0084 \\
\hline $\mathbf{7 5 0}$ & 1020.257 & 1144.466 & 1122.992 & 1018.604 \\
\hline $\mathbf{1 0 0 0}$ & 1160.117 & 1474.974 & 1504.114 & 1510.637 \\
\hline
\end{tabular}

Table 6:- Input Power

In this test when the speed is less than $500 \mathrm{rpm}$, if the load increases the torque is smaller so that the input power decreases. While at speeds of $750 \mathrm{rpm}$ to $1000 \mathrm{rpm}$, the generator has a peak load at a load of $10 \Omega$, can be seen in Figure 7 and table 6.

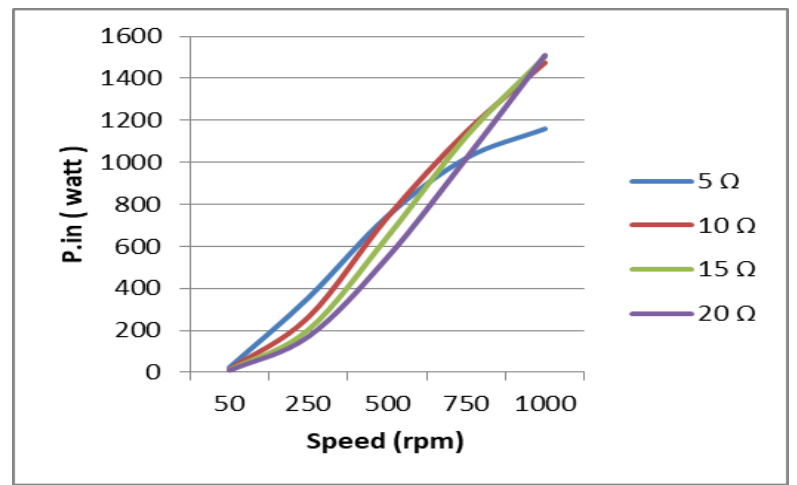

Fig 7:- Graph of Input Power to Speed

\section{Output Power}

Output power is the result of the conversion of angular velocity $(\omega)$ and torque $(\tau)$ which produces voltage $(\mathrm{V})$ and Current (I) by the generator. Table 7 shows the values of the output power with load variations at angular speeds of 50 rpm to $1000 \mathrm{rpm}$.

\begin{tabular}{|c|c|c|c|c|}
\hline \multirow{2}{*}{$\begin{array}{c}\text { Speed } \\
(\mathbf{r p m})\end{array}$} & \multicolumn{4}{|c|}{ Output Power (P. Out) watt } \\
\cline { 2 - 5 } & $\mathbf{5} \boldsymbol{\Omega}$ & $\mathbf{1 0} \boldsymbol{\Omega}$ & $\mathbf{1 5} \boldsymbol{\Omega}$ & $\mathbf{2 0} \boldsymbol{\Omega}$ \\
\hline $\mathbf{5 0}$ & 16.77699 & 10.00969 & 7.100117 & 5.4283 \\
\hline $\mathbf{2 5 0}$ & 275.6034 & 208.7378 & 161.0911 & 136.2341 \\
\hline $\mathbf{5 0 0}$ & 551.8332 & 580.791 & 514.4797 & 428.9553 \\
\hline $\mathbf{7 5 0}$ & 742.2479 & 870.5873 & 878.2817 & 803.9555 \\
\hline $\mathbf{1 0 0 0}$ & 822.104 & 1103.002 & 1145.662 & 1170.53 \\
\hline
\end{tabular}

Table 7:- Output Power

Figure 8 presents the data in graphical form, it appears that the higher the speed, the value of the power produced is also greater, but the generator also has a maximum load level, this can be seen in the variation of the speed of loading, such as the speed of $500 \mathrm{rpm}$. At a speed of 500 
$\mathrm{rpm}$, if the generator is given a load of $5 \Omega-10 \Omega$ the resulting in power increases, but after being given an increase in load from $10 \Omega-20 \Omega$ the resulting in power decreases, this also occurs in other speed variations. From the results of this experiment, if you want to optimize the performance of the generator, then the generator must function according to a certain speed and loading, so that the generator can work optimally.

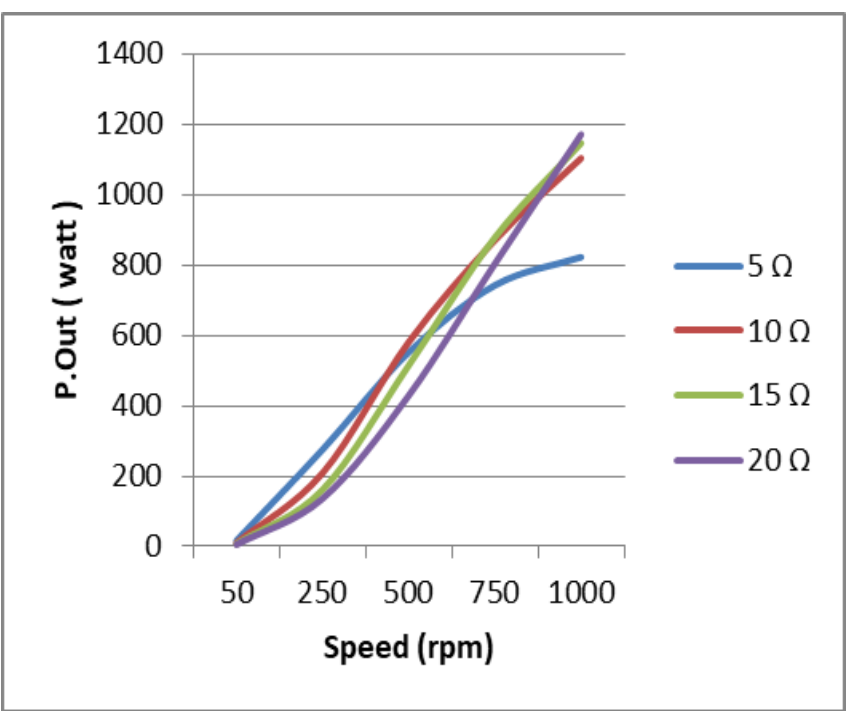

Fig 8:- Graph of Output Power Against Speed

\section{Efisiensi}

The simulation results of the efficiency of the generator that have been designed are shown in table 3.4. The efficiency of this generator changes due to the influence of the input value which is in the form of changing speed so that the generator torque also changes. In addition to the conversion into electricity, there are losses in the form of Edy currents and iron losses in the stator and rotor material.

\begin{tabular}{|l|l|l|l|l|}
\hline \multirow{2}{*}{ Speed (rpm) } & \multicolumn{4}{|l}{ Efficiency $(\boldsymbol{\eta})$} \\
\cline { 2 - 5 } & $\mathbf{5} \boldsymbol{\Omega}$ & $\mathbf{1 0} \boldsymbol{\Omega}$ & $\mathbf{1 5} \boldsymbol{\Omega}$ & $\mathbf{2 0} \boldsymbol{\Omega}$ \\
\hline $\mathbf{5 0}$ & 0.6936 & 0.659 & 0.6173 & 0.5719 \\
\hline $\mathbf{2 5 0}$ & 0.77388 & 0.792 & 0.7904 & 0.796581 \\
\hline $\mathbf{5 0 0}$ & 0.74153 & 0.7864 & 0.7976 & 0.7841 \\
\hline $\mathbf{7 5 0}$ & 0.7275 & 0.760693 & 0.782 & 0.7893 \\
\hline $\mathbf{1 0 0 0}$ & 0.7086 & 0.7478 & 0.7617 & 0.7748 \\
\hline
\end{tabular}

Table 8:- Efficiency

From the simulation data in table 3.4 , it can be seen that the worst efficiency occurs when the load is $20 \Omega$ at 50 rpm because it is only able to convert $57 \%$ energy. at the speed of $500 \mathrm{rpm}$, the smallest efficiency when loading $5 \Omega$ is equal to $0.72 \%$. The best efficiency occurs when loading 15 "at a speed of $500 \mathrm{rpm}$ converts $79.76 \%$ of energy. In detail, it can be seen in Figure 9.

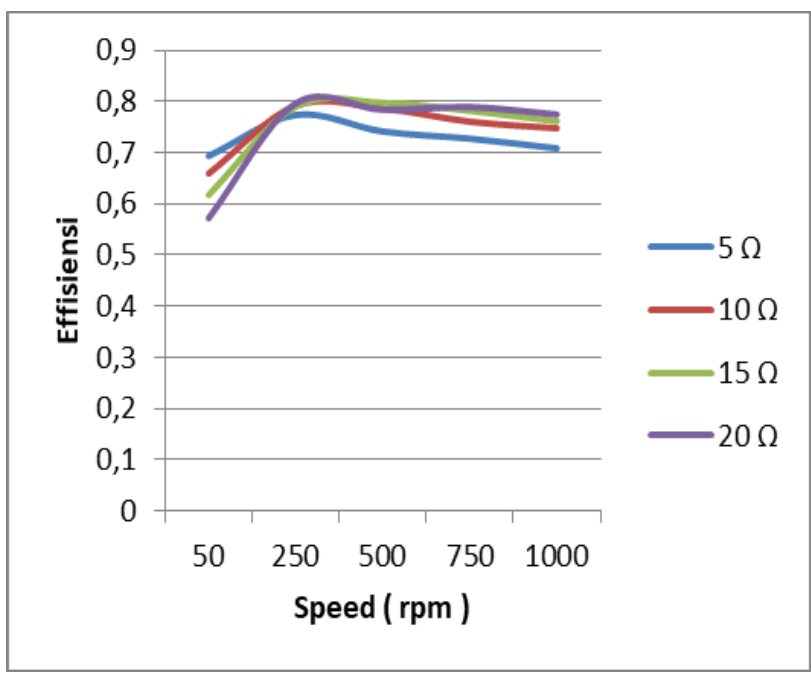

Fig 9:- Efficiency Curves Against Speed

\section{CONCLUSION}

This permanent magnet generator mini design has been successfully designed with a back-emf constant value of 2.16 , with the number of turns obtained the highest power produced at a speed of 500rpm is 580,791 watts. While the highest output power generated by the generator is at a speed of $1000 \mathrm{rpm}$ which is 1170.53 watts, and the lowest power at a speed of $50 \mathrm{rpm}$, which is equal to 5,4283 watts. The highest efficiency of this permanent magnet generator is $79.76 \%$

\section{REFERENCES}

[1]. Indonesia Energy Outlook, 2016. Badan Pengkajian dan Penerapan Energi, Indonesia. 2016.

[2]. LAN (2014). Pengenalan Teknologi Energi Angin. PT. Lentera Angin Nusantara

[3]. T. Rovio, H. Vihriälä, L. Söderlund, and J. Kriikka, "Axial and Radial Flux Generators in Small-Scale Wind Powerproduction," J. Chem. Inf. Model., vol. 53, no. 9, pp. 1689-1699, 2013.

[4]. B. J. Chalmers, W. Wu, and E. Spooner, "An axialflux permanent-magnet generator for a gearless wind energy system," IEEE Trans. Energy Convers., vol. 14, no. 2, pp. 251-256, 1999.

[5]. E. Spooner, A. C. Williamson, and G. Catto, "Modular design of permanent-magnet generators for wind turbines," IEE Proc. Electr. Power Appl., vol. 143, no. 5, pp. 388-393, 1996.

[6]. G. C. Lee, S. M. Kang, and T. U. Jung, "Permanent magnet structure design of outer rotor radial flux permanent magnet generator for reduction cogging torque with design of experiment," 2013 Int. Conf. Electr. Mach. Syst. ICEMS 2013, pp. 315-319, 2013. 
[7]. Parviainen, Asko. 2005. Design Of Axial-Flux Permanen-Magnet Low-Speed Machine And Performance Comparisson Between Radial-Flux And Axial-Flux Machine. Tesis. Lappenranta: Lappenranta University Of Technolgy.

[8]. Anam, M. Chairul. 2016. Perancangan Generator 100 Watt Menggunakan Software Elektromagnetik Infolytica. Skripsi. Malang: Jurusan Teknik Elektro Fakultas Teknik Universitas Muhammadiyah Malang.

[9]. Utomo, Agus R, Mesin Sinkron, Diktat Kuliah Teknik Tenaga Listrik, Departemen Teknik Elektro, Universitas Indonesia..

[10]. Chapman, S. J. 2005. Electric Machinaery Fundamental. Fifth Edition. Australia: McGraw-Hill.

[11]. Handershot, J. R dan Miller, TJE. 1994. Design Of Brushless Permanen Magnet Motor. Oxford: Clarendon Press dan Magna Physics publishing.

[12]. Azka, Mukhdil. 2013. Analisis Perancangan Dan Simulasi Generator Sinkron Magnet Permanen Dengan Rotor Berlubang. Skripsi. Depok: Program Studi Teknik Elektro Fakultas Teknik Universitas Indonesia.

[13]. Kenjo, T and Nagamori, T. 1985. Permanent-Magnet and Brushless DC Motors. New York : Oxford University Press.

[14]. Simanjuntak, Piala Ameldam. 2016. Perancangan Motor Thosiba. Lentera Angin Nusantara

[15]. I. Boldea, and A. N. Syed, The Induction Machine Handbook, Electronic Edition ed.New York, USA : CRC Press LLC, 2002. 